\title{
THE PROBLEMATICS OF SIMPLE LAWSUIT IMPLEMENTATION TO REDUCE CIVIL CASES IN SUPREME COURT
}

\author{
Bambang Sugeng \\ Ariadi S. \\ Fakultas Hukum \\ Universitas Airlangga \\ bambangsugengg1@gmail. \\ com
}

\section{Zahry Vandawati Ch. \\ Fakultas Hukum \\ Universitas Airlangga zahri.vandawati10@gmail.c om}

\begin{abstract}
This research has purpose to analyze the implementation of a simple lawsuit settlement to reduce the accumulation of civil cases in the Supreme Court. Also to analyze the constraints and obstacles in the application of simple claim resolution to reduce the buildup of civil cases and investigate the constraints and obstacles in the application of simple claim resolution to reduce the buildup of civil cases. This research is normative legal research that used the approach of statute approach and conceptual approach. The result of this research indicated that the implementation of simple lawsuit mechanismin court process could be quite helpful for citizen to settle the civil cases on state court with a quick process, simple system and low cost. In the context of implementing a simple lawsuit mechanism in court proceedings, there are several obstacles and have not maximally utilized in society, such as the minimum limit for the value of material claims is at most Rp. 200,000,000.00 (two hundred million rupiahs).
\end{abstract}

Keywords: Justice Principle, simple lawsuit, civil cases

\begin{abstract}
Abstrak: Penelitian ini bertujuan untuk menganalisis pelaksanaan penyelesaian gugatan sederhana yang dapat digunakan untuk mengurangi penumpukan perkara perdata di Mahkamah Agung, serta menganalisis kendala dan kendala dalam penerapan penyelesaian gugatan sederhana guna mengurangi penumpukan perkara perdata. kasus perdata dan menganalisis kendala dan hambatan dalam penerapan penyelesaian gugatan sederhana untuk mengurangi penumpukan kasus perdata. Penelitian ini merupakan penelitian hukum normatif dengan menggunakan pendekatan
\end{abstract}




\begin{abstract}
statuta dan pendekatan konseptual. Hasil penelitian ini menunjukkan bahwa penerapan mekanisme gugatan sederhana dalam proses peradilan dapat sangat membantu warga negara untuk menyelesaikan perkara perdata di pengadilan negara dengan proses yang cepat, sistem yang sederhana dan biaya yang murah. Dalam rangka penerapan mekanisme gugatan sederhana di pengadilan. Dalam proses persidangan terdapat beberapa kendala dan belum dimanfaatkan secara maksimal di masyarakat, antara lain, batas minimal nilai klaim materiil paling banyak Rp. 200.000.000.00 (dua ratus juta rupiah).
\end{abstract}

Kata Kunci: Prinsip Keadilan, gugatan sederhana, kasus perdata

\title{
Introduction
}

The Settlement of civil cases can be done either through the court (litigation) or outside (non-litigation). The Settlement of a case through the court was done through the process of examining related to the provisions of civil law procedure. The plaintiff expects a court decision regarding the proposed cases, when his demand is granted by the Judge, it will certainly help to fulfill his rights. However, practically the resolution by courts is too convoluted, takes much time, and inefficient.

The simple, quick and low-cost judicial principle arrangement has a purpose to eliminate concerns about law enforcement from foreign investors that invests in Indonesia, the concerns of other countries which include as Indonesia's business partners in implementing free trade, and at the same time, the most important thing is to reduce the accumulation of cases in Supreme Court, especially at Cassation stages. Along with the increasing number of submitted cases and those that were successfully decided in the District and High Courts, the number of decisions submitted to the Supreme Court at the Cassation level has also increased and begun to become a serious problem. 
According to Harifin A. Tumpa, the cause of case arrears1 happens because the first judge is not careful in deciding the cases, therefore the public questioned their sense of justice to the Supreme Court. This required several strategic actions, as stated by Henry P. Panggabean;

"Every year, It is confirmed that Supreme Court will not be able to handle the cassation cases, even if the amount of Judges is more than 51 people. The effort to prevent the huge number of cassation cases is not enough if it is only through the justice management approach without relating it to the change of legal requirement and assistance of systematic approach toward the court practice."2

Cases Arrears in the Supreme Court have implications for the function of the Supreme Court, which should examine the important cases that relevant to the function of maintaining unity in the law application.3 However, the Supreme Court is more oriented towards the number of delinquency cases, that affecting the consistency of decisions. Therefore the case arrears have an impact on the degradation of the main function of the Supreme Court as supervisor of legal unity.4 In this context, the strengthening of judicial functions at the first level of state court and level II (counterpart) is important in the context of limiting legal remedies, especially cassation legal measures, as an implementation of simple, quick and low-cost claims.

Regarding the accumulation of cases in the Supreme Court, it is caused by no regulations of restrictions on cassation and judicial remedies. The Restrictions on the attempts to submit cassation requests are required for: 5

1. Improve the decision quality

\footnotetext{
1 Harifin, "Pembatasan Perkara Dimasukkan Revisi UU MA," Yahoo Indonesia, 2019.

2 Henry P Panggabean, Fungsi Mahkamah Agung dalam Praktek Sehari-Hari: Upaya Pnanggulangan Tunggakan Perkara dan Pemberdayaan Fungsi Pengawasan Mahkamah Agung (Jakarta: Pustaka Sinar Harapan, 2001).

3 Harifin, "Pembatasan Perkara Dimasukkan Revisi UU MA." 4 Ibid.

5 Mahkamah Agung Republik Indonesia, Cetak Biru Pembaruan Peradilan 2010-2035 (Jakarta, 2010).
} 
2. Make it easier for the Supreme Court to map the legal issues.

3 . Reduce the number of cases at the cassation level which means reducing the workload of the Supreme Court.

The important effort that should be done to prevent the cases by functioning the state court or the second level (counterpart) to be the final court for certain cases, and it needed expansion criteria of cassation law effort limitation. For civil cases, several criteria that can be used to limit the concluded cases at the counterpart level can be examined in terms of case type and complexity.6 Consideration of case limitations based on the type and qualification of the case and not depend on the value of lawsuit. Based on several considerations, the limitation on the value is considered as subjective and obtained different interpretations, such as interpreting immaterial losses and the high value. Besides, the calculated values can change by the times. Thus, case limitation based on the type and case qualification is considered as more suitable.7 Without case classification, there is inefficient actions occurred because each panel of Supreme Court Justices examining the cases have the same legal issues and have to experience a process of research and debate in same duration.8 In order to create a simple, quick and low-cost justice principle, the Supreme Court has been release the regulation of Supreme Court number 2/2015 regarding Simple Lawsuit Resolution Procedure. According to the head of the Supreme Court, the purpose of this regulation as a way to reduce the number of intended cases.9 Riskawati added that some people are still complaining on the long process of litigation, thus PERMA (Supreme Court regulation) is issued as one of the ways to reduce the amount of cases.10 The terms of small claim court is

\footnotetext{
6 Mahkamah Agung Republik Indonesia.

7 Ibid.

8 Ibid.

9 Hatta Ali, "Urgensi Terbitnya PERMA Small Claim Court," Hukum Online.com, 2015.

10 Shanti Riskawati, "Peraturan Mahkamah Agung Nomor 2 Tahun 2015 Tentang Tata Cara Penyelesaian Gugatan Sederhana Sebagai Instrumen
} 
used to mark the case differentiation based on the nominal value which tend to be small.11 It also used to embody modern democracy State and enhance the best services for society. John Badwin defined small claim court or simple lawsuit as one of the dispute settlements that is informal, quick and low-cost.12 Therefore, it can be concluded that simple lawsuit has characteristic such as (a) informal which means the mechanism is different from the general court mechanism, (b) quick and efficient, (c) specific monetary amount.13

Simple, quick and low-cost principle has its own meaning. Simple refers to the investigation process which is clear, straightforward, non-interpretable, uncomplicated, easy to understand, easy to do, easy to be applied, sistematic, and concret either in the point of view of the justice seekers or the law enforcers.14 However, in its practice, simple is only interpreted as administrative problem without any understanding that simple principle can be the passion and motivation for law enforcer.

The meaning of quick handling on the justice principle includes the process of making court news and submitting copies of court decisions to the parties and minimizing the efforts of delaying the trial process without clear reasons. Not only quick but also consider the juridical consideration, accuracy, precision, and sociology consideration which guarantees a sense of community justice that also considered.

Perwujudan Asas Peradilan Sederhana, Cepat dan Biaya Ringan," Veritas et Justitia 4, no. 1 (June 28, 2018): 131-54, https://doi.org/10.25123/vej.2917. 11 Yulin Fu, "Small Claim and Summary Procedure in China," Brics Law Journal 1, no. 1 (2014).

12 Efa Laela Fakhriah, "Mekanisme Small Claims Court dalam Mewujudkan Tercapainya Peradilan Sederhana, Cepat dan Biaya Ringan," Mimbar Hukum 25, no. 2 (2013): 258-70.

13 Bustamar Bustamar, "Small Claim Court dalam Sistem Peradilan Perdata di Indonesia dan Peluang Penerapannya dalam Penyelesaian Sengketa Ekonomi Syari'ah Pada Peradilan Agama," ALHURRIYAH: Jurnal Hukum Islam 1, no. 1 (2016), https://doi.org/http://dx.doi.org/10.30983/alhurriyah.v1i1.483. 14 Bustamar. 
Quick here can enhance society's trust to the court15. Thus, this principle consists of quick in progress, quick in result, quick in evaluation toward the performance and productivity level of justice institution.

While, the meaning of low-cost is a court fee that can be reached by community, as stipulated in the explanation of Article 2 paragraph (4) of Law number 48 of 2009 concerning Judicial Power. Low-cost also intended to general public who have less in fund to file a lawsuit to the court. Besides, low-cost also conduct the meaning of looking for justice is not only expect for guarantee of justice but also consist of the guarantee that justice is not expensive, justice can not be materialized, and justice is Independence free from other values that will destroy its values.

In Indonesia, the term of simple lawsuit is often influenced by cases related to the consumers' right. The cases, such as the delayed flight by Lion Air with small claim number for 718.500 rupiahs 16 and the case for parking management with claim for 10.000 rupiahs.17 The implementation of simple, quick and low cost justice principle in examination and settlement of court cases should not leave the accuracy and precisión to find justice. Thus, in the process of resolving cases in justice court, it must be strictly enforced. This claim cannot be modified because the enforcement of justice is closely related to the enforcement of rights Uustice is peculiarly stringent. Its demands may not be modifled, because Justice is closely connected to respect for rights).18 According to Samuel Fleischacker each person

15 Fakhriah, "Mekanisme Small Claims Court dalam Mewujudkan Tercapainya Peradilan Sederhana, Cepat dan Biaya Ringan."

16 IHW, "Delay Pemberangkatan Penumpang, Lion Air Dihukum Ganti Rugi," Hukum Online.com, 2008, https://www.hukumonline.com/berita/baca/hol18432/idelayi-

pemberangkatan-penumpang-lion-air-dihukum-ganti-rugi/.

17 DetikNews, "MA: Kehilangan Kendaraan Saat Parkir Wajib Diganti Pengelola," detikNews, 2010, https://news.detik.com/berita/d1407260/ma-kehilangan-kendaraan-saat-parkir-wajib-diganti-pengelola. 18 Alan Ryan, Justice-Oxford Readings In Politics And Government (Oxford University Press, 1993). 
possesses an inviolability founded on justice that even the welfare of society as a whole cannot override.19 Therefore, justice should protect the inviolability of individual rights and even cannot be violated for the sake of society.

Moreover, if the simple, quick, and low-cost principles as described above become the spirit of law enforcers, thus an effective and efficient justice system can be realized. The criteria of simple, quick and low-cost principle are efficient, effective and, easy to reach for citizens.20 According to Sudikno Mertokusumo, the simple, quick and low-cost principle refer to a principle that clear, easy to understand and straight forward.21 As M. Yahya Harahap said that this principle is an examination process that does not take long time and relate to the simplicity of procedural law itself.22 Besides, it must not reduce the accuracy of examination and assessment of law and justice. Simple lawsuit has simple mechanism in solving cases with small claim number in a quick and simple way and low-cost payment, but its verdict has binding legal power.23 Thus this mechanism considered can reduce the number of cases in court, cut the complicated cases and facilitate society to reach for justice by putting forward the restorative justice.

Wahyuningsih, et al (2018) found that the application of simple lawsuit in Makassar based on PERMA (Supreme Court Regulation) Number $2 / 2015$ is not yet effective in time limitation since there is one case that exceed the limit for more than 25 days.24 Different with Zuhriah and Azmi (2019) who

19 Samuel Fleischeker, A Short History Of Distributive Justice (Harvard Press, 2004).

20 Lihat penjelasan Pasal 2 ayat (4) Undang-Undang tentang Kekuasaan Kehakiman.

21 Mertokusumo Sudikno, Hukum Acara Perdata (Yogyakarta, 1992).

22 Harahap M. Yahya, Kewenangan dan Acara Peradilan Agama (Jakarta: Pustaka Kartini, 1993).

23 Bustamar, "Small Claim Court dalam Sistem Peradilan Perdata di Indonesia Dan Peluang Penerapannya dalam Penyelesaian Sengketa Ekonomi Syari'ah Pada Peradilan Agama."

24 Sri Wahyuningsih, Lukman Ilham, and Irsyad Dahri, "Penerapan Sistem Gugatan Sederhana (Small Claim Court) dalam Penyelesaian Perkara 
found simple lawsuit as new innovation in religious court which focused on the distribution of right and obligation. The cases should be divided between voluntair and contentius cases to make sure that the distribution of the process is balanced.25 While Noor (2020) in his study indicated that simple lawsuit in its implementation give facilitate for society with quick process and low-cost payment. Simple lawsuit can only be used for wanprestasi and act against the law.26 Cases that can be solved using simple lawsuit or small claim court including; (a) the cases are clear and not ambiguous, (b) submission of consensus cases between the litigants, and (c) small cases or case with clear legal basic and the case object is less than 30\% from dispute object.27

Based on the explanation above, this research aims to determine and analyze the implementation of simple lawsuit settlement to reduce the amount of buildup civil cases. Also, to examine and analyze the obstacles on implementing the simple lawsuit settlement itself.

This research is a legal research (rechtsonderzoek) of a scientific process to resolve certain legal problems or issues to provide a prescription about what should be or what kind of legal issues that currently arise.28

Normative legal research is used since it is based on the distinctive character of legal science itself, such as legal

Wanprestasi di Pengadilan Negeri Makassar," Jurnal Tomalebbbi V, no. 1 (2018).

25 Erfaniah Zuhriah and Miftahuddin Azmi, "Model Small Claim Court Sebagai Alternatif Penyelesaian Perkara di Pengadilan Agama Perspektif Teori Keadilan John Rawls," De Jure: Jurnal Hukum dan Syari'ah 11, no. 2 (2019): 128-42, https://doi.org/http://dx.doi.org/10.18860/j-fsh.v11i2.6580.

26 Muhammad Noor, "Penyelesaian Gugatan Sederhana di Pengadilan (Small Claim Court) Berdasarkan Peraturan Mahkamah Agung Nomor 2 Tahun 2015," YUDISIA : Jurnal Pemikiran Hukum dan Hukum Islam 11, no. 1 (June 5, 2020): 53-66, https://doi.org/10.21043/yudisia.v11i1.6692.

27 Zuhriah and Azmi, "Model Small Claim Court Sebagai Alternatif Penyelesaian Perkara di Pengadilan Agama Perspektif Teori Keadilan John Rawls."

28 Henry Campbell Black, Black's Law Dictionary, West Publishing, Fifth Edit (United States of Amerika, 1979), https://doi.org/10.2307/1066423. 
normative research methods. This method is used to analyze statutory regulations, jurisprudence, and contracts. While, doctrinal research is used to analyze legal principles, legal literature, views of highly qualified law scholars (doctrine), and comparative law.

As the research used is normative legal research, the research approach used is statute approach and conceptual approach. Statute approach carried out by reviewing all laws and regulations related to the handled legal issues. Statutory approach is an approach using legislation and regulations.29 Conceptual approach departing from the legislation and doctrines developed in science of law.30

The Selection of research locations is around the area of Surabaya, Sidoarjo, Jakarta, Semarang, and Makassar. The location was chosen due to the large number of cases handled in District Courts of those cities, as well as the large number of laws and regulations and various literary research.

The legal material consists of Primary legal material which is every legal regulation that formally established and/or made by State institution, Government agencies for the sake of its establishment that will be pursued based on coercion carried out officially by state apparatus. Primary Legal material includes several law regulations. Secondary legal material consisted of materials related to primary legal material that provide an explanation of primary legal materials and help to analyze and understand primary legal materials such as various literary resources such as book, research, conference article and journal that related to the certain problem. Tertiary legal materials are legal materials that provide an explanation for primary and secondary legal materials. In this case, the tertiary legal material is law dictionary.

29 Peter Mahmud Marzuki, "Penelitian Hukum," Jurnal Penelitian Hukum (Jakarta, 2011).

30 Peter Mahmud Marzuki, Penelitian Hukum Edisi Revisi (Jakarta: Kencana, 2016). 
The research location is used based on the cases that needed to be handle in District Court in cities including; Surabaya, Sidoarjo, Jakarta, Semarang and Makssar.

\section{Basic Lawsuit Arrangement in Indonesia}

1. Constitution number 48/2009 regarding the judicial power

As what decided on article 2 number (4) and article 4 number (2) constitution number 48/2009 regarding the judicial power required the important principle on civil law that consist of simplicity, quick process and low-cost system. Simple means the examination and settlement of cases carried out in an efficient and effective way; low-cost is the cost of a case that can be acomplished by the citizen. However, the principle of simple, quick and low-cost in examination and settlement of cases should not rule out precision and accuracy in seeking truth and justice. Besides, Article 4 (2) of constitution number 48/2009 stipulates that in the context of implementing such principles in civil cases, the courts should help justice seekers and try their utmost to overcome all obstacles in order to achieve justice.

Moreover, it has been issued Letter of Indonesia Supreme Court number 6/1992 on case settlement in High Court and District Court on October, 21 1992. This letter regulated about the time limit on case settlement that no later than 6 (six) months with requirement such as; (1) if the time limit is over due, then it should be reported to High Court and Indonesia Supreme Court. Besides, based on the regulation of Supreme Court number $1 / 2016$ on the mediation procedure in Court, the implementation of simple, quick and low-cost is also put into mediation mechanism within the civil case examination.

2. Supreme Court Regulation Number 2 of 2015 jo and Supreme Court Regulation Number 4 of 2019 concerning on Procedures for Settlement of Simple Lawsuits

The simple lawsuit is a civil lawsuit with maximum material claim value of 500,000,000.00 (two hundred million rupiahs) which is settled by simple procedure and evidence. The settlement of simple lawsuit can only be done for breach 
of contract (wanprestasi) case or known as case of unlawful acts. The matter of breach of contract (wanprestasi) is a matter that arises as a result of non-fulfillment of an agreement, for example, $\mathrm{X}$ and $\mathrm{Y}$ bargaining on an item, $\mathrm{X}$ has handed over a certain amount of money, but $Y$ has not given the contract agreement that be delivered. Meanwhile, case of unlawful acts is a case arising from the loss of one side due to the actions of another side, however there is no prior agreement; for instance, $\mathrm{A}$ is hit by $\mathrm{B}$ in a traffic accident. $\mathrm{A}$ is injured and required a hospital medical expenses, thus $A$ can sue $B$ to compensate all the losses caused by B's act. The requirements to fill a simple lawsuit could be such as:

a. The plaintiff is an individual or legal entity;

b. There is a legal relationship which forms the basis of dispute with Defendant;

c. Plaintiff and Defendant are live in the same domicile/jurisdiction;

d. The dispute is not related to land rights or other matters that are specifically regulated in statutory regulations, such as business competition for consumer disputes and settlement of industrial relations.

e. The amount of maximum lawsuit or losses should be $500.000 .000,00$ (five hundred million rupiahs)

The scope of simple lawsuit, including the breach of contract (wanprestasi) and/or act against the law with claim value for 200 million rupiahs. While, the case which not included in simple lawsuit is case that the dispute settlement is done through special court as regulated within the constitution or dispute of land rights31. In Mainland China, the amount of the small claim payment is lower than $30 \%$ of the average annual wages of worker. This small claim court

31 Tri Jata Ayu Pramesti, "Seluk Beluk Gugatan Sederhana," Hukum Online.com, 2016, https://www.hukumonline.com/klinik/detail/ulasan/lt56a9cc2d21ea9/sel uk-beluk-gugatan-sederhana/. 
simplifies the procedure in step by step, from formal procedure to simple procedure32.

3. The Draft of Civil Code Procedure

In Article 79 of the Draft of Civil Code Procedure Chapter VII Part 3 on case examination with simple agenda, which declare that;

(1) On a certain day, the Head of the Court or appointed Judge held trial as single judge to examine, judge and decide the case with simple agenda which according to the dispute characteristic needed a direct examination and verdict.

(2) Clerk of the court noted on the filed cases to be examined with simple agenda in separated list of cases.

Meanwhile, Article 80 declares;

(1) The cases that can be examined, judged, and decided with simple agenda, including;

- Implementation on sentence or other legal product with executorial power,

- Notary has obligation to make deed or certificate which according to its condition cannot be delayed,

- Goods' sealing or opening the goods' seal or,

- Other civil cases that according to the parties needed an immediate action and can occur loss for the litigants if it is examined in general way.

(2) Sentence in simple agenda as in paragraph 1 can be done earlier though decision which filed on legal remedy.

Whereas, Article 85 states;

(1) Toward all sentence with simple agenda in first phase cannot be filed for appeal and can only be filed

$32 \mathrm{Fu}$, "Small Claim and Summary Procedure in China." 
for cassation to the clerk of the court who decides the case with simple agenda within period of 14 days (fourteen) counted after the decision have made.

(2) Toward cassation as written in paragraph 1 cannot be filed for application for reconsideration.

Based on the Indonesia Civil Code mentioned within the simple examination agenda, then the implementation of simple lawsuit as regulated in PERMA (Supreme Court Regulation) number 2/2015 jo, PERMA (Supreme Court Regulation) number 4/2019 is effective as legal reform.

\section{Implementation of Simple Lawsuit Resolution to Reduce the Accumulation of Civil Cases}

Based on the explanation on Article 2 number (4) of Law Number 48/2009 concerning on Judicial Power, it is stated that the simple, quick and low-cost principle are the most basic principles of justice in the implementation and administration of justice services that lead to the principles of effectiveness and efficiency. However, practically simple principle is only interpreted as a mere administrative problem without an understanding of the spirit and motivation for law enforcement officers which is carried out comprehensively at every level of judiciary.

The meaning of quick is the way in implementing the agenda which started from investigation, resolution until the verdict signing.33 Quick should be known as the strategic effort to make judicial system as institution that can guarantee the achievement of justice in law enforcement, as what stated on the explanation of article 2 number (4) constitution number $48 / 2009$. It is not only quickly resolved but also has juridical considerations, precision, accuracy, and sociological considerations that ensure the sense of justice of society. This aspect includes quick of process, quick of result, and quick of evaluation toward performance and productivity. While the meaning of low-cost is a low case cost which can be

33 Fakhriah, "Mekanisme Small Claims Court dalam Mewujudkan Tercapainya Peradilan Sederhana, Cepat dan Biaya Ringan." 
accomplished by citizen. However, in practice, simple principle only interpreted as a mere administrative problem without understanding that simple principle should become the soul and motivation for law enforcement officers.

Based on the explanation above, it needs a procedural settlement which is applied on the countries within the system of common law, by providing an authority to settle the cases related to the disputed object value. Therefore to obtain the quick disputed settlement, simple and low-cost, it needs a mechanism called Small Claim Court.

It should be known that there are two kinds of cases that could not be solved on the simple dispute, such as the cases which the dispute settlement is carried out through special court and cases of disputes over land rights, 34 as stipulated in Article 3 number 2 Supreme court regulation 4/2019. On the settlement of simple lawsuit, there is a process called dismissal proces, which means preliminary hearing of judge is authorized to assess and determine whether the matter meet the criteria of simple lawsuit.

For example, the first small claim court case is happen in State Court of North Jakarta with case number 01/Pdt.G.s/2015/PN.Jkt-Sel, listed as consultan cooperation service company, Smart Consulting, as plaintiff.35 This company file suit to the ex client from PT. Jasa Tambang Nusantara (PT JTN). The claim is filed since PT JTN imprident in paying the consultation fee for 96 million rupiahs. According to the judge, the claim which filed is based on the Supreme Court Regulation number 2/2015 requirement with claims under 200 million rupiahs. Moreover, the case is not through special court and did not involve land rights dispute. The plaintiff or defendant have same domicile within the juridiction of Jakarta State Court.36

\footnotetext{
34 Pramesti, "Seluk Beluk Gugatan Sederhana." 35 Ibid.

36 KAR, "Pertama Kali, Gugatan Sederhana Diperiksa PN Jakarta Selatan," Hukum Online.Com, 2016, https://www.hukumonline.com/berita/baca/lt56a333d1ed524/pertamakali--gugatan-sederhana-diperiksa-pn-jakarta-selatan.
} 
A simple lawsuit consists of a plaintiff and a defendant, and each of them cannot be more than one, except they have the same legal interest. In a simple lawsuit, the Plaintiff and Defendant are domiciled in the same jurisdiction. When the plaintiff is outside the jurisdiction of defendant residence or domicile in filing a lawsuit, the plaintiff appoints an attorney, incidental attorney, or a representative who having an address jurisdiction of defendant within the letter of assignment from plaintiff's institution. The stage in completion of simple lawsuit is no later than 25 days as regulated within Article 5 Number 2 and 3 Supreme Court Regulation number 2/2015, including; (a) Registration, (b) Completion Check, (c) Judge and Clerk of The Court Appointment, (d) Early Examination, (e) Trial Day Appointment and Trial Calling for Parties, (f) Court Examination and Justice, (g) Proofing, (h) Decision.37

The mechanism in filing simple lawsuit is by registrating to the clerk of District Court within the legal region of the defendant's domicile. The plaintiff is required to fill the form which contain with the identity of plaintiff and defendant, and short explanation on the claims. The clerk then do the requirements' check, if it is meet the requirement then the clerk will note it in the registration book for simple lawsuit, but if it is not meet the requirements then the clerk will return the claim back. The plaintiff also has obligation to pay the payment case, however if the plaintiff is unable to pay, he can apply for prodeo. 38

After that, the Head of District Court will assign a single judge to check the claim along with the clerk. In this phase, if the judge think that the claim is not categorized as simple lawsuit then he will remove the case from the registry and return the

37 Noor, "Penyelesaian Gugatan Sederhana di Pengadilan (Small Claim Court) Berdasarkan Peraturan Mahkamah Agung Nomor 2 Tahun 2015"; Hatta Ali, "Urgensi Terbitnya PERMA Small Claim Court," Hukum Online.com, 2015, https://www.hukumonline.com/berita/urgensi-terbitnya-perma-ismallclaim-court.

38 Noor, "Penyelesaian Gugatan Sederhana di Pengadilan (Small Claim Court) Berdasarkan Peraturan Mahkamah Agung Nomor 2 Tahun 2015." 
payment back. But if it is fulfill the requirement, then the first trial will be assigned. However, if the plaintiff did not attend on the first trial without any good reasons than the simple lawsuit will be stated as fail.

The time limit in simple lawsuit completion according to Article 5 paragraph 3 Supreme Court Regulation number $2 / 2015$ is 25 days from the first trial.39 The initial mechanism process to fill a lawsuit is simple as registering a simple lawsuit at Registrar's Office of District Court, which in its jurisdiction includes the residence of Defendant (asasactor sequitur forum rei). The Plaintiff is obliged to fill in the identity of the Plaintiff and Defendant, a brief description of the case and the Plaintiff's claim. The plaintiff is obliged to pay a court fee down payment. For those who cannot afford, they can submit a court proceeding for free (prodeo).

The application of simple lawsuit settlement mechanism in civil law of Indonesia has not been maximally utilized in society considering that the number of cases filed to court is not as many as those filed for ordinary claims. Based on the obtained information from data of all District Courts in Jakarta, the number of civil case examinations within the simple lawsuit mechanism is relative small compared to ordinary procedural hearings, because the value limit is 500,000,000.00 (five hundred million rupiah) for Jakarta and it relative small.

Meanwhile, the number of civil case investigations by simple lawsuit mechanism at the District Court outside Jakarta included as following below:

1. Based on the amount of civil cases in State Court of Surabaya 40 the amount that has been settled through the simple lawsuit mechanism is 92 cases in 2020, 207 cases in 2019, and 115 cases in 2018. It needs four months to settle the cases begin from the first trial until the verdict reading. Moreover, it will not take time for more than a year.

39 Noor.

40 Mahkamah Agung Republik Indonesia, "Sistem Informasi Penelurusan Perkara Pengadilan Negeri Surabaya,” 2015. 
2. The accumulation of civil cases in Sidoarjo State Court41 obtain 37 cases that has been settled in 2020 through the simple lawsuit mechanism, 93 cases for 2019, 54 cases for 2018, 22 cases for 2017, and 7 cases for 2016.

3. The accumulation of cases in Mojokerto State Court42 that has been settled in 2020 is 18 cases, 19 cases in 2019, 7 cases in 2018 , and 14 cases in 2017 . The case duration since the first trial to the verdict reading is 5 months, include a week of request and simple lawsuit required 15 days of work.

4. The accumulation cases in State Court of Jombang43 were 64 civil cases that examined and decided through a simple lawsuit mechanism from 2020 data, 191 cases from 2019 data, 80 cases from 2018 data, 38 cases on 2017, the averages duration to settle the case from the first hearing depend on the range of mediation from 4 to 6 months.

5. Based on the cases on Semarang State Court that has been settled through simple mechanism is 37 cases in 2020, 51 cases on 2019, 29 cases on 2018, and 6 cases on 2017.

6. Based on data, there were 48 civil cases in Makassar Court that were successfully resolved through a simple lawsuit mechanism for 2020, 204 cases of 2019, 137 cases from 2018, 20 cases of 2017, 3 cases for 2016.

Based on the entire data on examination of civil cases by a simple lawsuit mechanism at Jakarta District Court and several District Courts outside Jakarta, the total calculated indicated that simple lawsuit mechanism can help to obtain a simple, quick and low-cost judicial principles. At the same time it can help to reduce the accumulation of cassation cases at Supreme Court. This is related to the objective of Supreme Court Regulation number 2/2015 jo and Supreme Court Regulation number 4/2019 concerning on Procedures for Settlement of Simple Lawsuits.

\footnotetext{
41 Mahkamah Agung Republik Indonesia, "Sistem Informasi Penelusuran Perkara Pengadilan Negeri Sidoarjo," 2015.

42 Mahkamah Agung Republik Indonesia, "Sistem Informasi Penelusuran Perkara Pengadilan Negeri Mojokerto," 2015.

43 Mahkamah Agung Republik Indonesia, "Sistem Informasi Penelusuran Perkara Pengadilan Negeri Jombang," 2015.
} 


\section{Constraints and Obstacles to the Application of Simple Claim Settlement}

The simple lawsuit mechanism is the procedure for examining civil cases by material claim value which is not exceed $500,000,000.00$ (five hundred million rupiahs) and was settled by simple way of proof. Thus, what clearly distinguishes a simple lawsuit from an ordinary lawsuit is the value of material losses which is more specifically determined in a simple lawsuit, which is a maximum of 500,000,000.00 (five hundred million rupiahs). While in a lawsuit of ordinary civil cases, the value of material losses is not limited. Besides, simple proof has time duration of 25 days and should be examined and decided by the main judges in the scope of competences of general judicial bodies. Thus, the purposes of Supreme Court regulation concerning on simple lawsuit is to fasten the process of settlement related to the principle of simple, quick and low-cost system to reduce the accumulation case of Supreme court.

Based on the entire data of civil cases examination, it is stated that lawsuit has not been maximally utilized in community, especially when the minimum of material lawsuit is $200,000,000.00$ (two hundred million rupiahs) which is not accommodating in simple lawsuit matters. However, after regulation number $4 / 2019$ has been published, that regulates the value of material lawsuit at most 500,000,000.00 (five hundred million rupiahs), there is an increase in the number of cases filed by simple lawsuit mechanism, including Makassar District Court.

In the court practice, the explanation of norms concerning on the meaning of simple proof is very insufficient and can even be said to be vague (vague norm). The vague of norms can create a legal uncertainty and even can be abused44. The existence of uncertainty made it more difficult for to file a simple lawsuit to Court. For this reason, in order to make the proof done simply, the reference that contains in posita and petitum in lawsuit must

44 Cakrawala, "Mendekonstruksi Sistem Pebuktian Sederhana dalam Kepailitan," Unair News, 2019. 
be simply implemented either voluntarily or through execution. For example, a petitum that possibly granted is only related to the validity of agreement, there is wanprestasi and punishment and the obligation to make compensation, and the voluntary execution mechanism. However, if it is not implemented voluntarily, an execution auction is requested.

Furthermore, the provision of article 4 number $2 / 2015$ is explained as below:

a. The parties in simple lawsuit consist of plaintiffs and defendants, each of them should not more than one, unless they have the same legal interests.

b. The defendant with unknown place of residence in a simple lawsuit cannot be filed.

c. Plaintiff and defendant in the simple lawsuit are domiciled in the same jurisdiction of the same Court.

d. Plaintiffs and defendants are required to attend each trial with or without the assistance of legal representative.

Thus, in a simple lawsuit examination, it is not mandatory to represent a lawyer / advocate as in the case of ordinary civil cases. However, the parties (plaintiffs and defendants) with or without legal attorneys / advocates are required to attend in person at the trial. Thus, every parties, whether represented or not represented by a lawyer / advocate, are obliged to attend the trial from the first trial until the decision was made.

Another obstacle is the absence of mechanism for calling the first trial for the parties in Supreme Court regulation number 2/2015 jo and Supreme Court regulation number 4/2019 explained that the summon was made directly by the clerk / bailiff as in a normal case summons or using the e-court mechanism. It is supported by Wahyuningsih, et al (2018) in their findings that the mechanism on the implementation of simple lawsuit is unregulated, especially on the forced effort of simple claims.45 Sakina, et al (2018) also found that the

45 Wahyuningsih, Ilham, and Dahri, "Penerapan Sistem Gugatan Sederhana (Small Claim Court) dalam Penyelesaian Perkara Wanprestasi di Pengadilan Negeri Makassar." 
application of simple lawsuit in Despansar State Court work very well, even if there is still vagueness in Supreme Court Regulation number $2 / 2015$ on procedures of simple lawsuit settlement which lead to misinterpretation in its practice. They also added the factors that obstruct the implementation of simple lawsuit, including the lack of good intention from the litigants, and there is still a lot of people who did not understand even know about simple lawsuit.46 In Supreme Court number 2/2015 in Article 31 Paragraph 2 that verdict with legal source is implemented voluntarily. However if the verdict cannot be done voluntarily, then foreclosure is one of the way to define the court decision.

Thus, it needed a new mechanism on summoning the defendant and plaintiff to the court by electronic mail or email, especially at the first trial summoning when the position of the parties or one of the parties is outside the jurisdiction area, the electronic mail should be done in order to prevent the case settlement which has been limited by two days of work.

\section{Conclusion}

The application of simple lawsuit mechanism in the process of litigation in front of court is actually quite helpful for the community to quickly resolve the civil cases in the District Court, simple and only need low cost for the examination data of civil cases by simple lawsuit mechanism at Jakarta District Court and several District Courts outside Jakarta, such as Surabaya, Sidoarjo, Mojokerto, Jombang, Semarang and Makassar. Moreover, if it is being calculated, the entire amount indicated that simple lawsuit mechanism can help to obtain simple, quick and low-cost trial principles, and at the same time it help to reduce the accumulation of cassation in Supreme Court.

In the context of implementing simple lawsuit mechanism of litigation process before the court decision there are several obstacles that still has not been maximally utilized in community, such as the minimum limit for value of material

46 Sakina Sakina, Dewa Nyoman Rai Asmara Putra, and I Gusti Ayu Agung Ari Krisnawati, "Penerapan Penyelesaian Sengketa dengan Gugatan Sederhana (Small Claim Court) di Pengadilan Negeri (Studi Kasus di Pengadilan Negeri Denpasar)," Kertha Wicara 7, no. 4 (2018). 
lawsuit at most Rp. 200,000,000.00 (two hundred million rupiahs). However, after the Supreme Court Regulation number 4/2019 is issued the number of filed cases is increased.

Furthermore, there is still an obstacle in the implementation of simple lawsuit, such as the requirement for both plaintiff and defendant, with or without attorney, to attend the court, the vagueness of Supreme Court number 2/2015. Also the mechanism in calling for first trial which consuming more on time. Therefore, it is suggested to use electronic mail or email for calling due to make the process is not obstructed. Thus, the implementation of simple lawsuit can be done quickly.

Based on the conclusion above, it can be recommended that an active role of law enforcement officials is needed, whether judges or advocate, to socialize the benefit of simple lawsuit mechanismin court proceedings related to the application of quick principles, simple and low-cost justice. It needs clear arrangements in context of implementing the application of simple lawsuit mechanism in court proceedings related to simple evidence.

\section{References}

Ali, Hatta. “Urgensi Terbitnya PERMA Small Claim Court.” Hukum Online.com, 2015.

——_. "Urgensi Terbitnya PERMA Small Claim Court." Hukum Online.com, 2015. https://www.hukumonline.com/berita/urgensiterbitnya-perma-ismall-claim-court.

Black, Henry Campbell. Black's Law Dictionary. West Publishing. Fifth Edit. United States of Amerika, 1979. https://doi.org/10.2307/1066423.

Bustamar, Bustamar. "Small Claim Court dalam Sistem Peradilan Perdata di Indonesia dan Peluang Penerapannya dalam Penyelesaian Sengketa Ekonomi Syari'ah Pada Peradilan Agama." ALHURRIYAH: Jurnal Hukum Islam 1, no. 1 (2016).

https://doi.org/http://dx.doi.org/10.30983/alhurriyah. v1i1.483.

Cakrawala. "Mendekonstruksi Sistem Pebuktian Sederhana 
dalam Kepailitan." Unair News, 2019.

Fakhriah, Efa Laela. "Mekanisme Small Claims Court dalam Mewujudkan Tercapainya Peradilan Sederhana, Cepat dan Biaya Ringan." Mimbar Hukum 25, no. 2 (2013): 25870.

Fleischeker, Samuel. A Short History Of Distributive Justice. Harvard Press, 2004.

$\mathrm{Fu}$, Yulin. "Small Claim and Summary Procedure in China." Brics Law Journal 1, no. 1 (2014).

Harifin. "Pembatasan Perkara Dimasukkan Revisi UU MA." Yahoo Indonesia, 2019.

IHW. "Delay Pemberangkatan Penumpang, Lion Air Dihukum Ganti Rugi." Hukum Online.com, 2008. https://www.hukumonline.com/berita/baca/hol18432 /idelayi-pemberangkatan-penumpang-lion-airdihukum-ganti-rugi/.

KAR. "Pertama Kali, Gugatan Sederhana Diperiksa PN Jakarta Selatan." Hukum Online.Com, 2016. https://www.hukumonline.com/berita/baca/lt56a333d 1ed524/pertama-kali--gugatan-sederhana-diperiksapn-jakarta-selatan.

M. Yahya, Harahap. Kewenangan dan Acara Peradilan Agama. Jakarta: Pustaka Kartini, 1993.

Mahkamah Agung Republik Indonesia. Cetak Biru Pembaruan Peradilan 2010-2035. Jakarta, 2010.

_- - "Sistem Informasi Penelurusan Perkara Pengadilan Negeri Surabaya," 2015.

- - - "Sistem Informasi Penelusuran Perkara Pengadilan Negeri Jombang," 2015.

- - - "Sistem Informasi Penelusuran Perkara Pengadilan Negeri Mojokerto," 2015.

———. "Sistem Informasi Penelusuran Perkara Pengadilan Negeri Sidoarjo," 2015.

Marzuki, Peter Mahmud. "Penelitian Hukum,." Jurnal Penelitian Hukum. Jakarta, 2011.

-_- Penelitian Hukum Edisi Revisi. Jakarta: Kencana, 2016.

Noor, Muhammad. "Penyelesaian Gugatan Sederhana di 
The Problematics of Simple Lawsuit...

Pengadilan (Small Claim Court) Berdasarkan Peraturan Mahkamah Agung Nomor 2 Tahun 2015." YUDISIA: Jurnal Pemikiran Hukum Dan Hukum Islam 11, no. 1 (June 5 , 2020):

53-66.

https://doi.org/10.21043/yudisia.v11i1.6692.

Panggabean, Henry P. Fungsi Mahkamah Agung dalam Praktek Sehari-Hari: Upaya Pnanggulangan Tunggakan Perkara Dan Pemberdayaan Fungsi Pengawasan Mahkamah Agung. Jakarta: Pustaka Sinar Harapan, 2001.

Pramesti, Tri Jata Ayu. "Seluk Beluk Gugatan Sederhana." Hukum Online.com, 2016. https://www.hukumonline.com/klinik/detail/ulasan/lt 56a9cc2d21ea9/seluk-beluk-gugatan-sederhana/.

Riskawati, Shanti. "Peraturan Mahkamah Agung Nomor 2 Tahun 2015 Tentang Tata Cara Penyelesaian Gugatan Sederhana Sebagai Instrumen Perwujudan Asas Peradilan Sederhana, Cepat Dan Biaya Ringan." Veritas et Justitia 4, no. 1 (June 28, 2018): 131-54. https://doi.org/10.25123/vej.2917.

Ryan, Alan. Justice-Oxford Readings In Politics And Government. Oxford University Press, 1993.

Sakina, Sakina, Dewa Nyoman Rai Asmara Putra, and I Gusti Ayu Agung Ari Krisnawati. "Penerapan Penyelesaian Sengketa dengan Gugatan Sederhana (Small Claim Court) di Pengadilan Negeri (Studi Kasus di Pengadilan Negeri Denpasar)." Kertha Wicara 7, no. 4 (2018).

Sudikno, Mertokusumo. Hukum Acara Perdata. Yogyakarta, 1992.

Wahyuningsih, Sri, Lukman Ilham, and Irsyad Dahri. "Penerapan Sistem Gugatan Sederhana (Small Claim Court) dalam Penyelesaian Perkara Wanprestasi Di Pengadilan Negeri Makassar." Jurnal Tomalebbbi V, no. 1 (2018).

Zuhriah, Erfaniah, and Miftahuddin Azmi. "Model Small Claim Court Sebagai Alternatif Penyelesaian Perkara di Pengadilan Agama Perspektif Teori Keadilan John Rawls." De Jure: Jurnal Hukum dan Syari'ah 11, no. 2 (2019): 128-42. 
Bambang Sugeng Ariadi, Zahry Vandawati

https://doi.org/http://dx.doi.org/10.18860/jfsh.v11i2.6580.

DetikNews. "MA: Kehilangan Kendaraan Saat Parkir Wajib

Diganti Pengelola." detikNews, 2010.

https://news.detik.com/berita/d-1407260/ma-

kehilangan-kendaraan-saat-parkir-wajib-digantipengelola. 